\title{
Actually existing capitalism: some digital delusions
}

Paul Thompson \& Kendra Briken, Universities of Stirling and Strathclyde

Contemporary labour process analysis (LPA) emphasises the intimate connections between transformations of capitalism and trends in work and employment. Within social theory influential images of labour such as Reich's (1993) symbolic analysts or Castell's (1996) selfprogrammable workers, ultimately derive from conception of the broader economy, in this case informational capitalism or the knowledge economy. Their diagnosis is based on the following assumptions. First, the sources of profit, productivity and power in the new economy are said to be (variously) intangible, immaterial or weightless (knowledge, creativity, information, intellectual assets). Digital products are reproducible at low cost for high returns, enabling capitalism to overcome scarcity and 'the limits of time and space' (Castells 2001, 5). Second, that knowledge-intensive, intellectual or professional work is either in the majority or becoming the majority in advanced post-industrial societies. Third, there has been a decisive shift of power from capital to labour given that '(knowledge) 'remains with the employee and in no real sense is it ever of the firm. It is impossible to separate knowledge from the knower' (Despres and Hiltrop, 1995, p. 11). Fourth, that traditional, hierarchical structures and practices of management are no longer appropriate, with the best practice being to hire talented people, then leave them alone (Florida 2002, p. 132). Fifth, corporate forms have mutated into decentralised, flat, networked organisations. Extensive critique of these claims have been made elsewhere and we will not repeat them here (Thompson et al 2001; Thompson 2004; Thompson and Harley 2012). What we do want to do is look in more detail at a related, but newer version that comes under the heading of cognitive capitalism, in part because it will facilitate a more extended engagement with issues of digital industries and labour.

Theorists of cognitive capitalism influenced by autonomist Marxism (Hardt and Negri 2009; Böhm and Land 2011; Moulier Boutang 2012) build on many of these themes. Such claims offer a significant challenge to LPA as they defy the idea of material production as a privileged site for the value extraction and antagonism between capital and labour. The policy agenda offered by more recent popularisers (Mason 2016; Sirnicek and Williams 2015) shifts even further away from the work terrain in so far as the workplace in itself is no longer understood as a place for neither collective nor individual resistance. This chapter counters with a detailed exposition and critique of a theories of cognitive or digital capitalism. Drawing on our own and other labour process research, within that critique we offer some observations towards a more realistic picture of capitalism at work, including the importance of financialization of the economy.

\section{Cognitive capitalism}

Cognitive capitalism theory (CCT) derives from a combination of Italian (post) operaismo ${ }^{1}$ and French regulation school influences (Hardt and Negri 2000, 2004, 2009; Vercellone

${ }^{1}$ Operaismo refers to an intellectual and political tradition that formed in Italy in the 1960s and 1970s and whose contemporary prominence is associated largely with the various works of Hardt and Negri. The term 
2007; Moulier-Boutang 2012; Corsani 2012 and see Turchetto2009; Jeon 2009 and Boffo 2012 for lineage and variations).

The core of the theory is that cognitive capitalism (CC) is a third type of capitalism (after mercantile, industrial) with a distinctive system of accumulation based on knowledge value: 'a mode of production in which the object of accumulation consists mainly of knowledge, which becomes the basic source of value, as well as the principal location of the process of valorisation'. (Moulier Boutang 2012, p. 57). Though CC emerges from the crisis of Fordism, theories of post-Fordism are dismissed as rooted in a neo-industrialist vision and relying on a traditional approach to the contradictions of capitalism. Instead, the new system of accumulation is characterised by a profound transformation of the antagonistic relation of capital and labour, and the conflicts that derive from it: The term 'cognitive brings to light the novel nature of labour, the sources of value and the forms of value' (Lucarelli and Vercellone 2013, p. 7). The 'production of knowledge by knowledge' therefore puts the traditional categories of political economy - value, ownership, production, labour - in crisis (Corsani 2001, p. 16).

Value extraction is based on knowledge that cannot be measured, thus value is produced by the 'general intellect' through socially cooperative labour or outside the workplace in the 'commons' (notably through the web and on-line communities) or by biopolitical labour in the production of social life itself (Hardt and Negri 2009; Mason 2016). Because of an abundance of use-values, increased returns and minimal cost of reproduction, scarcity disappears other than that of time and attention (Moulier Boutang, 2012, p. 66/72). Information 'corrodes value' in general and price mechanism for digital goods in particular (Mason 2016, pp. 142-3). Any account of value based on labour time in production, material production or commodity-producing labour is held to be in crisis. ${ }^{2}$ It is here where we find the connection between CCT and 'post-capitalist' visions: 'It is impossible to properly value inputs, when they come in the form of social knowledge, knowledge-driven production tends towards the unlimited creation of wealth, independent of the labour expended' (Mason 2016,p. 136).

As Boffo (2012, p. 265) notes, for CCT each of the above stages of the historical development of capitalism is also associated both with a specific form of division of labour and a dominant sector of the economy. With respect to the former, CC, with its increase in abstract knowledge and intellectual powers in production is associated with 'a radical change of the subsumption of labour to capital and indicates a third stage of the division of labour' (Vercellone 2007, p. 15). Vercellone frames this change by using Marx's distinction between formal and real subordination of labour. Marx made this distinction to emphasise the ways in which capital's use of machinery and science in what was then the modern factory enables new and more powerful mechanisms of control and value extraction,

'workerism' relates primarily to the orientation of linking stages of capitalism to figures of labour or class composition of labour. Post-operaismo broadly refers to the development of this tradition in a new era after Fordism and the mass worker.

${ }^{2}$ Though sceptical of much of the claims of new sources of value in the totality of social life and the ending of the distinction between production and reproduction, for space reasons our critique here is focused on challenging the arguments that value creation and extraction no longer takes place in or is marginal to the labour process and production. This counter-argument does not depend on the Marxian labour theory of value. 
overcoming what was previously just the general control of the employer that lacked the means to affect the actual mode of working (Marx 1976, p. 1011). Thus three stages of the division of labour are envisaged by Vercellone: formal subsumption of labour in the early factory system, real subsumption beginning in the industrial revolution and reaching its peak in the standardised mass production and 'Smithian' division of labour of the Fordist era, and finally the general intellect under CC in which real subsumption is reversed. Whereas the concept of formal and real subsumption was developed by Marx through his analysis of the labour process in Volume One of Capital, the general intellect is taken from the Grundrisse and in particular a series of unfinished notes - 'The Fragment on Machines'. Here it is envisaged that at some time in the future knowledge developed through science and technology will become the source of real wealth rather than labour expended in production. This would mark the possibility of a transition to communism. For CCT that time has arrived. Communism, or at least its preconditions, is already in existence (see Vercellone $2007,15)$, or, with Mason, at least postcapitalist becomes necessary and possible (2015, p. xiii) ${ }^{3}$.

With respect to a dominant sector, 'the new information technologies, of which the digital, the computer, and the Internet are emblematic in the same way in which the coal mine, the steam engine, the loom and the railroad were emblematic of industrial capitalism' (MoulierBoutang, 2012, p.57). There is a particular focus on software in general and open source in particular as a model of the new capitalism and value production. Mason emphasises the growth of 'non-market production: horizontally distributed peer-production networks, that are not centrally managed, producing goods that are either completely free, or - which being Open Source - have very limited commercial value', with Wikepedia as the primary example (2016, p. 143), In addition, for some, the creative or cultural industries, particularly digital games, play a key role because of the combination of autonomous workers, collaborative work and 'free labour' in the 'outernet' to the networking of human intelligence and production of value (Terranova 2000; de Peuter and Dyer-Witherford 2005).

Not only is the division of labour a marker of stages of capitalism, for the operaismo tradition labour and labour process dynamics are the primary drivers of development. The crisis that ushered in CC was not linked to issues of accumulation or profits, but contradictions within capital's control of the division of labour and the need for capital to free itself of the 'mass worker' (Vercellone 2007, and see Boffo 2013, p. 264; Turchetto 2008, p. 294). This tradition is therefore characterised by seeking to identify an emblematic figure of labour based on a specific 'class composition'. For CC, it is immaterial labour; defined variously as that which is cerebral, affective, communicative or relational, or that which contributes to the informational or cultural content of a commodity (Lazzarato 1996). As a result, there is a (qualitative) hegemony of intellectual labour or 'diffuse intellectuality'. Purely physical labour power is consigned to the Fordism and Taylorist era of industrial capitalism. Unlike that era, cognition and conception are no longer appropriated by capital, and living labour is no longer incorporated into science and machinery (Vercellone 2007, 16). Rather innovation is captured in interactive cognitive processes of social cooperation: 'The main source of value now lies in the creativity, versatility and...invention of employees and not in capital assets and in the work of execution' (Vercellone 2007, p. 25-26). The

${ }^{3}$ This argument of the general intellect and the Fragment on Machines is not confined to Vercellone. It is shared by Negri, much of the operaisomo tradition (Turchetto 2008, p. 295) and by Mason (2016, pp. 134-5). 
development of the general intellect is associated with the expansion of mass education, which develops alongside the welfare state during Fordism. It is not entirely clear what the causal links are between the two. One can only infer that diffuse intellectuality is somehow facilitated by the growth and character of educated, graduate, labour. A clue can perhaps be seen in Moulier-Boutang's somewhat naïve statement that, 'Postgraduates cannot be commanded in the same way as high school leavers' $(2012$, p. 68).

To the extent that any of these theorists refer concretely to the organisation of work specialisation, standardisation and codification are all decreasing. Reflecting on interactive information work, Moulier Boutang asserts that, 'There is no fixed system that determines ex ante the selection of resources to be mobilised on the basis some checklist, the division of operations, or the sequence of action with agents at each stage of operations...' (2012, p. 65). Assertions of autonomous immaterial labour are also linked to claims concerning measurement or more precisely its absence. Reinforcing he previous argument about labour time no longer being linked to value, autonomous labour is and is 'outside measurement' and beyond management: 'Immaterial labour is immeasurable because being measured means being imposed, which is in diametrical opposition to its being flexible, creative and communicative. Labour becomes life itself' (Jeon 2009, p. 6).

Moulier-Boutang links the rise of living labour to a decline of managerial interest in individual performance in the workplace $(2012$, p. 54). Meanwhile Vercellone (2007,p. 33) repeats the previously-noted knowledge economy argument that 'In cognitive-labour producing knowledge, the result of labour remains incorporated in the brain of the worker and is thus inseparable from the knower'. As for any engagement with ideas of managerial hierarchy or the firm, it is to repeat post-Fordist and mainstream business notions of the horizontalization of corporate forms; an economy of variety and learning organisations; small series of production (Moulier-Boutang 2012, p. 69) and networks displacing markets and hierarchies, except with an emphasis on digitalization (see Moulier-Boutang 2012,pp. 61-5). Mason also refers to the 'age of the network' and 'Everything comes down to the struggle between network and hierarchy, between old forms of society moulded around capitalism and new forms of society that prefigure what comes next' (2016, p. xix).

Despite the Marxist language, it is irrefutable that there are many similarities to prior new economy narratives ${ }^{4}$. A partial critique of the contradictions of cognitive capitalism emphasises the efforts by capital to offset the losses incurred in the law of value in production by enforcing it elsewhere. Capital uses its monopoly position in networks to manufacture scarcity through the extraction of rents based largely on intellectual property (see Vercellone 2007, pp. 33-34), or expropriates value produced in the wider society from the 'general intellect'. The distinction between profit and rent collapses and capital becomes purely 'parasitic' (see Boffo 2012, p. 261). One perceived consequence is that antagonism is displaced from the labour process and employment relationship and 'the class struggle in cognitive capitalism increasingly takes the form of a distribution struggle' (Jeon 2010: 19). In slightly different terms, politics shifts from the factory to the social

${ }^{4}$ In Empire, Hardt and Negri borrow wholesale from such sources (see Thompson 2005). The continuity is even more stark in Mason whose 'Prophets of Post Capitalism' chapter includes positive expositions of Peter Drucker, Kevin Kelly and Jeremy Rifkin, writings whose relationship to the reality of contemporary capitalism is somewhat distant (Mason 2015, pp. 109-45) 
factory, radical demands focusing on a universal basic income and full automation replacing the 'drudgery' of wage labour (Mason 2016; Snirceck and Williams 2015). There are few discussions of increased precariousness in the labour market and devaluation of labour power, but they remain relatively marginal to the main argument ${ }^{5}$.

\section{Social theory meets social facts}

It would be insufficient to critique CCT empirically as it is not about the validity of facts and numbers, but how they are interpreted' (Jeon 2010, p. 3). And certainly CCT is cavalier in dismissing evidence based criticisms on the grounds that hegemony might not actually be dominance, but the start of something or the directionality of trends (Moulier-Boutang 2012 , p. 54 / 60). But the latter's contempt for the 'empirical approach' should not go unchallenged, for two reasons. First, specific empirical claims are made about trends that can be challenged on their own terms. Second, because CCT is all too typical of the sweeping generalisations, unrepresentative exemplary industries and absence of plausible evidence that characterises much of the recent social theorising about capitalism. We will challenge the general arguments and assumptions contained in the CCT narrative by focusing on key trends in capital, employment and the division of labour.

\section{Actually existing capital}

Immaterial or cognitive knowledge materialises as a location of the process of valorisation. Yet we are told little or nothing about how capital is actually organised in companies or value chains, or how companies make their money through particular business models. Of equal importance, CCT overestimates the extent to which capitalism is defined and dominated by internet-based companies. If we look at data about which industries and firms dominate the global economy, it was in 2011 that for the first time a technology firm, namely Apple, overtook EXXON. In 2016, we find that Google's parent company Alphabet, Apple, Microsoft and Facebook are the world's most profitable companies (Myers 2016). However, they are far from being the largest either by revenue or capitalisation, let alone by employees; and many of the other 'exemplary' internet firms are marginal, with Uber and AirBnB not even showing up in the Fortune Global 500 list. In sum, global capitalism is dominated by energy, finance and telecoms/utilities. At European level financial services and supermarkets are strongly represented. In the UK, the story is similar, but with two global tobacco companies making the top twenty.

Of course, such lists are limited in their explanatory value and some of the activities producing profits for such firms will be knowledge-driven or internet-coordinated. But if anyone examines how Exxon Mobil, Wal-Mart or Toyota makes its money, it does offer a major corrective to the CCT narrative of immaterial production or zero cost reproduction ${ }^{6}$ at

\footnotetext{
${ }^{5}$ An exception is Snirceck and Williams (2015) for whom precarity and breakdown of stable jobs are a central feature of the crisis of work and emergence of a 'surplus population'.

6 'Zero cost reproduction' and immaterial production still depend on rather material worlds, examples are the ongoing and aggressive extractivism (with fracking but its latest turn), making sure basic crude materials most are available. The precision of new robots is available only by moulding plastic; processors rely on rare earth compounds; the power for cloud computing still stems from centralised energy production systems; robots still are a cost-intensive investment $(\$ 60,000$ up to $\$ 150,000)$; last not least, companies still get hold of intellectual property rights.
} 
the heart of economic value. The global dimension and the dynamics of value chains are also a key consideration. The example of Apple, Foxconn and the IPad is revealing. Apple's operating profit margin and stock market valuation is highly dependent on a business model based on cost control through the supply chain (Froud et al 2014) and specifically, very low direct labour costs in suppliers (Cleland 2014). Foxconn is compelled to pass on the burden of cost adjustment through speed-up, contract manipulation and various forms of free labour (including unpaid overtime and the dormitory labour system). In his critique of Mason, Fuchs sums up the picture effectively, 'This analysis overestimates information economy because capitalism is not just digital and informational capitalism, but at the same time financial capitalism, hyper-industrial, fossil fuel capitalism, mobilities capitalism etc' (Fuchs 2016, p. 232). He goes on to refute Mason's claim that value has collapsed in the digital sector, pointing to profits made on the basis of product innovation, exploitation of direct and indirect labour and (most significantly) targeted advertising. It is simply not true that 'capitalism can no longer adapt to technological change', as new ways to monetise and monopolise in those social media and Web 2.0 sectors show (Tyfield 2015; Coonawara 2015).

A key trend across all sectors is the concentration of capital. In contrast to the fantasy of the global commons, concentration is particularly marked in virtual and vertical integration internet-based or new media (Fitzgerald 2015). As Andrew Keen (2014) observes, the internet, contrary to images of a sharing economy, has proven to be the perfect vehicle for free market capitalism - a 'networked kleptocracy'. Mason notes the existence of 'infomonopolies', but beyond asserting that it is a 'defence mechanism' finds it difficult to explain if the 'spontaneous tendency' of information and the internet is to 'dissolve markets and destroy ownership' (2016, p. xiv). It seems to us the reverse is true. Peer production and genuine sharing economy projects exist in specialist niches, whilst digital platforms such as Uber and AirBnB develop hierarchical business models that invade and seek to dominate more traditional markets. It is telling that it is hard to find any substantive, collaborative peer production example in Mason other than Wikipedia.

\section{Employment - Jobs trends and the scope of digital labour}

The hegemony of cognitive labour is difficult to spot amongst statistics on employment. Table 1 gives an overview from the Bureau of Labour Statistics for projected US job growth. This indicates that growth will be based largely on the expansion of personal services, retail and hospitality - sectors that are associated with significant skills under-utilisation (Wright and Sissons 2012). CCT could argue that much of this work, whilst lacking 'intellectual' content abounds with the other immaterial dimension of affectivity and allowing for the general intellect to flourish. However, the positive spin by CCT seems to ignore the weight of evidence concerning the growing regulation and standardisation of emotional and aesthetic labour power (see Warhurst et al 2009). Indeed it is ironic given the casting of physicality back into the Fordist era that so much interactive service work draws on embodied capacities in labour power (Wolkowitz and Warhurst 2010).

Insert Table 1 here 
Returning to general trends, a UK report (Wilson et al 2014) estimated that the proportion of low and middle skilled jobs in 2022 would be 71 per cent - almost no change from the 2012 figure. Of course, as Table 1 shows, there is also job growth among some categories of professional, managerial and technical labour confirming long-established observations concerning polarised labour markets (Goos and Manning 2007). Scepticism concerning 'mass intellectuality' is reinforced by reports of a discrepancy between the number of graduates and 'graduate jobs' in both the US and UK (CIPD 2015). In a commentary on the US figures, Bernick (2012) observes that 'the main point remains from these projections that most jobs in the emerging economy are not ones requiring college degrees and above'. It may be objected that these are US and UK figures and it's true that we need a global picture. Why not start with the fact that there are almost 100 million manufacturing jobs in China alone (The Globalist, 2014)? As feminist, and post-colonial critics have noted (see Federici 2004 and Huws 2007) a dynamic analysis of the changing global divisions of labour is more global picture is precisely what is missing in CCT.

What of the employment trends concerning digital-related labour itself? Given the pervasiveness of digital tools and means of communication, there is a tendency to make inflated claims for its scope and coverage (e.g. Fuchs 2014, p. 352). Though by no means comprehensive, we would distinguish between three overlapping categories. First there is what we would describe as core digital labour defined in terms of creating and maintaining digital commodities, including software, games workers and parts of the 'creative class'. Whilst the relevant industries generate significant amounts of value, they do so largely on the basis of smaller, specialised labour forces. For example, the games industry in the UK currently generates $f 1.02$ bn contribution to GDP, yet it employs just 9896 workers in games development and up to 18,000 indirectly. Even more starkly, WhatsApp only needs about 50 employees to reach its 900 million users worldwide (Metz 2015).

The second category encompasses work that is allocated and/or organised through digital platforms. This is often associated with crowdsourcing, which is clearly a qualitative change with regard to employment relations (see Howcroft and Bergvall-Kareborn, this volume), but with different business models. At one end of the spectrum, mostly non-digital labour is recruited and organised through digital platforms to provide services to individuals or organisations such as TaskRabbit (from cleaning to moving to repair services) and Uber. On the other, companies - whether digital or not - outsource work through a kind of 'internalized offshoring' (Silverman 2014, p. 108). Much of the content - through platforms such as Amazon's Mechanical Turk - consists of microtasks, often with low skill and training requirements, and minimal rewards). However, platforms can also host contests for jobs with medium range complexity (translating articles; customer services) and even high-end jobs such as software development that are better compensated. Across the spectrum, the platforms offer the possibility of internationalising the available skill pool and evade national labour standards (Holts 2013). This is an important new trend, but again it is worth being cautious about the scope. According to a World Bank report on online outsourcing, there is an estimated 48 million worker registered on crowdsourcing platforms, but with only around approximately ten per cent actively participating $(2015$, p. 9).

The third category includes the large amount of routine labour employed directly by or in digital sectors. This includes, for example, 'behind the click' workers employed by the e-tail 
giants in Amazon and other warehouse, distributive and logistics centres, who use digital tools to keep the 'value in motion' (Newsome 2015). Alternatively, a UK Government report (DCMS 2014) estimates that though the proportion of jobs in the whole of the 'creative economy' - is at 8.5 per cent of total employment and growing, almost one third $(2.55 \mathrm{~m})$ were classified as 'non creative'.

The essential point being made here is that digital-related labour is of growing significance, but heterogeneous in content and context and uneven in any relationship to intellectual labour. The latter point is further illustrated in the next section.

\section{Curbing creativity: The case of the games industry}

The games industry is often regarded as exemplary of changes in the cognitive division of labour, the rise of autonomous, immaterial work and and the blurring of work/play boundaries (O'Doherty and Wilmott 2009; De Peuter and Dyer-Witherford 2005). Games workers are certainly an example of what we described earlier as 'core digital labour' involved in the production of digital commodities. Yet is we examine the largest component - console games - a very different picture emerges than one of autonomous, networker firms and workers. Digital games is a multi-billion dollar global industry. In terms of its value chain, there is a complex but heavily weighted struggle for value capture between console manufacturers and/or publishers, development studios and retailers. Game publishers such as Microsoft or Electronic Arts use their concentrated market power, access to finance and greater mobility/switching capacity to extract value in the chain, notably in the form of intellectual property and transfer of costs and risk. (Johns 2006). When it comes to employment relations, drawing on extensive research (Parker, Cox and Thompson 2014; Thompson, Parker and Cox 2015) it is possible to track how publishers can use digitalised technologies to outsource work to an increasingly spatially dispersed firms or 'development studio's. Sources of tension and conflict are then embedded in the contractual process. Managing this contract variation therefore creates significant budgeting and time scheduling pressures. The studio owners cannot meet the burden of that risk and the targets imposed by the lead firms without transferring a large portion of the risks to labour. Whilst the labour process does indeed involve creative cooperation, it is increasingly specialised and very far from unmanaged and improvised. Given that there are enhanced pressures for greater work intensity and pressure to 'do more with less', the above research found absolutely no evidence of the blurring of work and play. In fact even asking the question of interviewees was to invite scorn.

\section{Division of labour - Cognition, control and measurement}

CCT relies heavily on claims concerning the division of labour. Assertions of spontaneous social cooperation and autonomy bear little relationship to any workplace research we are aware of. European surveys report uneven trends concerning levels of employee discretion, 
with the majority of countries largely static er falling (Green 2006).. The autonomy argument is intimately linked to those concerning (the absence of) time and measurement. Labour time remains a fundamental focus of managerial attention. Indeed the use of tracking and monitoring software provides tools that FW Taylor could only have dreamed of. Nor is it confined to call centres and the minute measurement of call handling times. Amazon is known to use a digital platform that is multi-faceted, (Bergvall-Kåreborn and Howcroft, 2014) thus serving several ends simultaneously: vendors access to display and sell their wares, end customers can gain access to information on purchase and delivery status. This allows Amazon to evaluate the quantities required against in-stock availability, and managers can assess the "hourly flow of workers required in each part of the FC, supervisory can monitor associates in real-time (productivity, time targets errors etc.)", and they are able to text messages to the handheld devices that navigate the workers through the warehouse (Briken et al 2016, p.10) As one worker put it: “...the targets are in your face - literally - every second, of every minute, of every day (Maddy S)" (Briken et al 2016, p.11). Or, more bluntly in the words of an Amazon manager: "You're sort of like a robot, but in human form," said the Amazon manager. 'It's human automation, if you like'. (Financial Times, February 8, 2013)

Measurement in the service of a calculative rationality is thus wider than the question of labour time. The recent growth of 'people analytics' has been described in The Wall Street Journal as a trend that 'treats the humans in an organisation just like any other asset in the supply chain, as something that can be monitored, analysed and reconfigured' (Mims 2015). This can be considered a small aspect of the wider increase in performance management in large organisations. With respect to crowdsourcing platforms discussed earlier, Silverman notes that 'Everything they do is tracked' and that 'crowdsourced workers are expected to work seamslessly with software, following its commands' (2014, p. 108-9). In the private sector, it is primarily linked to cascading and often punitive targets, aided in many cases by electronic monitoring and tighter work flow (Taylor 2013, pp. 46-7). In the public sector, targets have accompanied the rise in 'new public management', but are also present in the spread of audit and accountability measures. What has become fashionably known as knowledge management (KM) is also part of enhanced performance exposure. $\mathrm{KM}$ is particularly significant in knowledge-intensive industries, the supposed heartland of creative and cooperative labour. Of course these characteristics are present, but alongside the use of IT systems to capture, convert and codify the tacit knowledge of expert labour in order to speed up the innovation or molecule to market process (McKinlay 2005). This is the common language used in the KM field and somewhat skewers the naïve view that knowledge cannot be appropriated from the mind of the intellectual worker.

The use of IT systems to capture tacit knowledge is now part of a widespread recognition of the emergence of digital or knowledge-based Taylorism. In manufacturing this is driven by the development of engineering systems that allow global operating companies to 'calculate, to compare and to standardise processes worldwide' (Westkämpfer 2007, p. 6). Brown et al (2011) refer to digital Taylorism as the extraction, codification and digitalisation of knowledge into software prescripts and working knowledge that underpins the global

${ }^{7}$ According to the first findings available from the Sixth European Working Conditions survey, we can see a slight increase compared to 2005 (Eurofund 2015, p. 7). However, this is not yet included in the positive changes mentioned in the reports summary.
Commented [KB1]: Might check for an updated source since this is ten years old?

Commented [KB2R1]: So I included the latest figures - see footnote below. OK? YES, but why not just give the reference and delete the footnote? 
auction of cheaper, high quality high skilled labour.). We also know that artificial intelligence and algorithms can incorporate living labour into machine systems. At the moment this is largely confined to mid-level jobs based on collection and analysis of information, but it has the capacity, as noted in a radio interview with McAfee to 'outsource cognitive labour' (BBC Radio 4, 2015). ${ }^{8}$

\section{Conceptual confusions}

Beyond linking these empirical limitations, a number of conceptual confusions are worth highlighting. First, despite references to systems of accumulation, the (post) operaismo legacy is of defining capitalism by stages in the division of labour or the dominant 'figure of labour'. On the latter, moving from the mass worker through various intermediary categories to the contemporary 'multitude' (Hardt and Negri) or the collective worker of the general intellect' (Vercellone), the result is a politicised version of value in search of 'the transcendental political subject in struggle against capital' (Boffo, 2012,p. 279). On the wider question, defining a stage of capitalism - real subsumption - that spans more than 150 years highlights the flaws in using the division of labour as the focal point. Whilst sociologists of work and the economy should always try to identify the ways in which capitalist political economy and the labour process are articulated, history teaches us that accumulation regimes are compatible with significant differences in the organisation of work and employment and, therefore, the frontier of control in the workplace. Leading contributors to CCT may try and justify their claims through Marx.

'Read(ing) the structure of capital' through the struggles of labour (Vercellone 2007,p. 25) leads to the second issue - the disappearing capital trick. This absence is exacerbated by designating capital as purely parasitic, with accumulation taking place through rent-seeking rather than profit in production. In taking this position CCT diminishes capital's power and evades any attempt to analyse its actual workings. It is true that in some sectors, intellectual property is a source of value capture, but rent-seeking through monopoly is not a new feature of capitalism and nor does it exhaust how firms use their power in markets and value chains. The choice to focus on value extraction through rent-seeking or outside production and in the 'totality of social life' is also at odds with contemporary employer attacks on the wages and conditions of labour (Boffo 2012,p. 267) and as we have already demonstrated, the continuing centrality of extracting value from labour in supply chains.

Contemporary capitalism is not just read through labour, but through the labour theory of value, or more precisely its abolition in an era in which value and labour time cease to have relevance as knowledge is socialised and governed by the general intellect. Mason has a long defence of the labour theory of value up until the point where info goods and their associated effects throw capitalism into crisis and provide the basis for a transition to postcapitalism. Along with the autonomists, this argument is derived, as indicated earlier, from The Fragment on Machines. Whatever the validity of Marx's arguments about the development of science, technology and automation as a basis for a transition to a post-

${ }^{8}$ Beaudry et al argue that an increase in such tasks is required during the period of investment in the new IT systems, but 'once the new capital is in place, cognitive task workers are only needed to maintain the new capital.' (Beaudry 2013, p. 2) 
capitalist future, it is clear that we are far from this point. As we have shown, not only is much of value capture taking place in traditional ways and through non-digital sectors, and capital has been extremely successful in finding new ways to valorise new ICTs and social media, both within and outside the labour process (Pitts 2015; Tyfield 2015). Without this understanding the arguments lead to determinism and/or utopianism as mentioned by a number of his critics (Fuchs 2016: 237; Pitts 2015), attributing to (Info) technology transformative powers - in this case to dissolve markets and ownership - that it does not and cannot independently possess.

Finally, the misapprehension of the present is sustained by a misreading of the past notably the designation of the 'industrial stage' of capitalism as based on physical labour., 'devoid of any intellectual or creative quality' (Vercellone 2007, p. 24). As Jeon (2010, p. 15) notes, 'industrial and cognitive labour are contrasted to each other to the extent that appear as if mutually exclusive'. As Marx (1977, p. 270) noted, labour power is always an 'aggregate of those physical and mental qualities'. Over-emphasis on the role of knowledge now is matched by its underestimation in the past. Not only were there significant numbers of design, engineering or other conceptual jobs under Fordism, those involved primarily in execution still contained tacit knowledge that employers are now seeking to identify and leverage (Warhurst and Thompson 2006).

\section{Financialization, capital and the digital}

To use a term to define the character or essential logic of capitalism in general or at a particular stage is a very large claim. It is, as we have demonstrated with respect to cognitive, informational or digital, both contentious and flawed. With respect to digital, this more accurately refers to particular commodities, sectors or tools used by a wider range of companies. In contrast we would highlight financialization as the central dynamic in contemporary capitalist political economy (Thompson 2013; Van der Zwan 2014). Though it can be conceptualised in varied and broader ways, we endorse the perspective that refers to a finance-dominated regime of accumulation, with the emphasis on a shift in the interconnections and pattern of dominance in the industrial and financial circuits of capital (Stockhammer 2008; Müller 2013; Demirovic and Sablowski, 2013). The scope of this concept includes both the role of financial assets in macro-economic patterns of growth and household behaviour and the micro-economic consequences of partially financialized accumulation at the level of the firm and the labour process. These dynamics are, of course, always uneven and contested, especially with respect of national political economies to incentivise or constrain the opportunities of financial agents (Engelen and Konings 2010: 618).

Within some of the core texts of CCT discussed in this chapter there are occasional and brief mentions of financialization (e.g. Vercellone 2007, p. 23; Moulier Boutang 2012, p. 48), but they are marginal to the central arguments and (given the GFC) inconsistent with assumptions about the relative stability of a new system of accumulation (Moulier Boutang 212 , p. 58). A partial exception amongst autonomist writers is Marazzi's (2010) account of the 'violence of financial capitalism'. However, whilst correctly identifying the unstable nature of accumulation, Marazzi persists with the theme that sees contemporary value capture as external to production. In this instance, finance becomes a further device to 
capture value produced either in social life/consumption, or in branding and intellectual property rights. The latter is indeed an important source of value under financialization (Willmott, 2010), but this argument fails to understand the continuing intimate connections between financialization, material production and the labour process. This holds true for Masons' (2015) occasional discussion of financialization. Here it is presented largely as an additional income stream for firms whose sources of profits through traditional business models are squeezed, and for workers facing wage squeeze, debt and in need of credit.

CCT thus follows the dominant policy discourse and relies on the contrast between financial institutions - notably new investment funds such as private equity - and their often speculative and predatory behaviours, with the real, productive economy. This distinction is largely illusory as non-financial corporations are themselves financialized in terms of their ownership, investment patterns and trade in financial assets (Clark and Macey 2015; Cushen and Thompson 2016). Capital market actions and actors thus increasingly drive firm behaviour rather than merely act as financial intermediaries. Some accounts of the pursuit of shareholder value tend to focus on redistribution processes, including increasing investor returns via dividends, share buybacks, taking on debt, and reducing internal investment and costs. Amongst the noted effects are perpetual restructuring, disposability of corporate assets, and a bias for short-term financial engineering and value extraction, and against operational capability and innovation. Various studies have noted the increased gap between the rate of return on manufacturing investment and the rate of return on financial assets (Milburg, 2009). Whereas the loyalty of corporate executives is secured through share option based rewards, the influence of weakening of unit-level managerial layers and levers is weakened. Of equal importance the weight of evidence is that financialization is destructive of the kinds of organisational innovation that CCT proclaims as the source of knowledge value, even in knowledge-intensive firms (Lazonick and Mazzucato 2013; Gleadle et al 2014).

Of course digital/informational tools and techniques facilitate financial flows, measurements and transactions. An example would be capital market valuation methodologies to measure performance, and aid the setting of financial targets in decision making. However, as the business analyst Simon Caulkin (2014) notes, the effects are largely negative, 'the management innovation that is needed will not come from new communication and coordinating technologies (such as big data, the internet of things or social media). In fact, the reverse is true. In today's financialized world, these are more likely to be used to accentuate the job-stripping, winner takes-all trend already seen with pervious techniques of outsourcing and offshoring. To return to the issue of value capture in the labour process, it is important to understand why and how these processes of financialized investment feed through to budgeting processes through which targets relating to revenue growth and cost cutting can be disseminated and measured. As Cushen and Thompson (2016) explain, these rely strongly on cost controls, with implications for labour and the labour process. This manifests itself in two main ways. First, cost recovery through taking labour out, outsourcing, work intensification and a downward squeeze on wages. Second, a shift in control mechanisms with an increase in the extent, intensity and punitive character of performance management. These are frequently linked to 'managed exits' of sections of the labour force and reflect the ratcheting down of financialized corporate profit targets (Clark and Macey 2015). Amongst the consequences for labour and 
its management are increased job and role insecurity associated with perpetual restructuring and reorganisation, and falling levels of employee engagement and attachment, with corresponding increases in cynicism and dissent.

\section{Some concluding comments}

Significant transformation has taken place in the workings of capitalism and some of those have been facilitated by digitalisation, including new sources of value and types of employment relation. However, our general examination of CCT reveals that it repeats most of the analytical mistakes of speculative grand narratives: stages as complete ruptures with the past; exemplary but atypical industries and work; technological determinism and utopianism; evidence-light speculation. In his trenchant critique of 'post-workerism', Graeber observes that it is 'less interested in describing realities than in bringing them into being' $(2008$, p. 13). The tendency to let the political goals drive or displace the empirical investigation is repeated in much of recent the post-work commentary (Mason 2016; Srnicek and Williams 2015). For example, after a series of definitive claims about emergent job-destorying automation, the latter admit that 'Our argument here relies largely on a normative claim rather than a descriptive one. Full automation is something that can and should be achieved, regardless if whether it is being carried out' (Srnicek and Williams 2015, p. 117)

Hence our critique of CCT has focused on what we believe to be going on in firms, work and labour markets. What we have given less consideration to is the more recent shift in autonomist-influenced and related claims that the rise of robot and Al-driven automation signals the end of any meaningful politics of production. It is true that some routine, midlevel and higher value jobs are vulnerable to the impact of $\mathrm{Al}$ and robotics in the next few decades (Brynjolfsson and McAfee 2014; Bank of England 2015). However, that has to be set against the fact that in mid-2016 the UK employment rate (at 74.2\%) was the joint highest since comparable records began in 1971 (Inman 2016). In a caustic critique of Mason, the radical economist Doug Henwood (2015) says that there is no evidence that info tech is substantially diminishing the amount of work needed and points to the fact that employment expansion in the US is even stronger than GDP growth models would suggest. With current trends in mind, it seems a very large number of steps to projections of a post work world. ${ }^{9}$

The figures in Table 1 also underline that in many of the jobs where there is a significant upward trend, notably in human services, they will not be easy to replace by robots given their often interactive and affective character. Given that knowledge-intensive and high discretion jobs are also unlikely to be automated, the roles with the most likely vulnerability are those (such as insurance underwriters and travel agents) where software can automate information search and manipulation. With respect to robots, manufacturing remains the main immediate market for robotics. According to the World Robotics 2015 report, the number of robot installations has increased heavily as since 2010 . However, this does not

${ }^{9}$ We are aware that the employment rates are contested. Looking at the global data published by the Worldbank, we see a global decline with some countries even increasing their participation rates. So far, the decline in some countries (China) is explained more accurately by economic crisis and not by technological determinism (Worldbank 2016). 
put into question the growth model for developing countries - low wages, cheap labour - in the near future. In developing economies, rather than replacing human labour, technology is more likely to enhance and augment human potentials (see Pfeiffer xxx in this volume). With robots becoming more dexterous, and are safe enough to work alongside people, there will for sure be an increase in Human-Robot-Collaboration (Bauer et al. 2008). Also, data gloves and data glasses will be used to increase quality (and potentially workers') control.

At this stage we don't know enough to predict with any certainty how many jobs softwaredriven automation and robotisation will eliminate, augment, decompose or create new demands for. What we do know is the stock of work in any economy is not fixed (Stewart et al 2015). It is also worth remembering that we have been here before with previous waves of technological determinist predictions from futurists and other ideational entrepreneurs of the 'end of work' (e.g. Rifkin 1995). Such determinism not only lacks a sound empirical basis, but an appreciation of agency. To avoid the same mistakes, analysis of the future role of the digital in capitalism needs to embrace an understanding of the varied contexts, power relations, choices and decision structures, and capacity for resistance. This has always been a strong point of labour process research. In contrast, rationales for a politics of postcapitalism and post-work rest on extremely pessimistic readings of the struggles of waged workers. In recent accounts from Mason (2016) and Srnicek and Williams (2015) the working class (in both developed and developing economies) is presented as fragmented, divided and in thrall to consumption and debt, whilst the labour movement is largely defeated, demoralised and sclerotic. In doing so, they dismiss the diverse, actual struggles and concerns of labour. It is vital to understand the content of those concerns and actions. Contrary to the claim that, 'For the vast majority of people, work offers no meaning, fulfilment or redemption' (Srnircek and Williams 2015, p. 117), survey and qualitative research indicates simultaneous positive attachments to work and work identity, but critique of and anger about insecurity, recognition, under-employment, work intensification, depressed wages and unfair rewards (see Findlay and Thompson forthcoming; XXX this volume). It is here where the discussion about digitisation and robotisation needs to be connected to real work experiences. Workers are critical about their jobs and how work is organised, but there is evidence that they want those concrete problems addressed rather than dismissed Fordist nostalgia. 


\section{References}

BBC 4 (2015) When robots steal our jobs, http://www.bbc.co.uk/programmes/b0540h85, date accessed 18 July 2016.

Beaudry, P, Green D. A. and Sand, B. (2013) The great reversal in the demand for skill and cognitive tasks, Paper provided by Suntory and Toyota International Centres for Economics and Related Disciplines, LSE, STICERD - Public Economics Programme Discussion Papers (22).

Benkler, Y. (2006) The Wealth of Networks: How Social Production Transforms Marks and Freedom, New Haven: Yale University Press.

Boffo M. (2012) 'Historical immaterialism: from immaterial labour to cognitive capitalism', Int. J. of Management Concepts and Philosophy, 6, 4, 256- 279.

Böhm, S., and Land, C. (2012) The new 'hidden abode': reflections on value and labour in the new economy. The Sociological Review, 60(2), pp.217-240.

Bureau of Labor Statistics (2016) Occupations with the most job growth, http://www.bls.gov/emp/ep_table_104.htm, date accessed 18 July 2016

Brown, P., Lauder, H. and Ashton, D. (2011) The Global Auction: The Broken Promise of Education, Jobs and Incomes, Oxford: Oxford University Press.

Brynjolfsson, E. and McAfee, A. (2014) The Second Machine Age. Work, Progress, and Prosperity in a Time of Brilliant Technologies, New York: Norton.

Castells, M. (1996) The Rise of the Network Society: The Information Age Economy, Society and Culture. Oxford: Blackwell. Vol. 1.

Castells, M. (2001) The Internet Galaxy: Reflections on the Internet, Business, and Society, Oxford: Oxford University Press. Vol. 3.

CIPD (2015) Over-qualification and Skills Mismatch in the Graduate Labour market, Chartered Institute for Personnel and Development, London.

Cleland, D. (2014) 'The Core of the Apple: Dark Value in Global Commodity Chains', Journal of World Systems Research, 20,1, 82-111.

Corsani, A. (2012) Wage/Labour Relations' in Neoliberal Cognitive Capitalism, http://artesliberales.spbu.ru/events/afisha/news_12_06_29txt/news12_06_29Corsa ni, date accessed 17 July 2016.

Cushen, J. and Thompson, P. (2016). 'Financialization and value: why labour and the labour process still matter', Work, Employment \& Society, 30,2, 352-365.

DCMS (2014) Creative Industries Economic Estimates 2014, Department for Culture Media and Sport: London. 
de Peuter, G. and Dyer-Witheford, N (2005) 'A Playful Multitude? Mobilising and CounterMobilising Immaterial Game Labour', Fibre Culture 5, http://five.fibreculturejournal.org/fcj-024-a-playful-multitude-mobilising-andcounter-mobilising-immaterial-game-labour/, date accessed 18 July 2016.

Despres, C. and Hiltrop J.M. (1995) 'Human Resource Management in the Knowledge Age', Employee Relations, 17,1, 9-23.

Deuze, M., Bowen M.C. and Allen, C. (2007) 'The Professional Identity of Gameworkers', Convergence: The International Journal of Research into New Media Technologies, 13, 4, 335-353.

Dörre, K. (2013) 'Finance Capitalism, Landnahme and Discriminating Precariousness Relevance for a New Social Critique', Social Change Review 10, 2, 125-151.

Eurofund (2015) First Findings. Sixth European Working Conditions Survey. EF/15/68/EN. Brussels.

Federici, S. (2004) Caliban and the Witch: Women, the Body and Primitive Accumulation. Brooklyn, NY: Autonomedia.

Findlay, T. and Thompson, P. (forthcoming) 'Work and its Meanings', Journal of Industrial Relations.

Fitzgerald, S. (2015) Structure of the Cultural Industries - Global Corporation to SMEs, in: Kate Oakley und Justin O'Connor (Hg.) The Routledge Companion to the Cultural Industries, London: Routledge, 70-85.

Florida, R. (2002) The Rise of the Creative Class, New York: Basic Books.

Froud, J., Sukhdev, J., Leaver, A. and Williams, K. (2014) 'Financialization across the pacific: Manufacturing Cost Ratios, supply chains and power', Critical Perspectives on Accounting, 25, 46-57.

Fuchs, C (2014) Digital labour and Karl Marx. New York: Routledge

Gill, R. and Pratt, A. (2008) 'In the Social Factory? Immaterial Labour, Precariousness and Cultural Work', Theory, Culture and Society, 25, 7/8, 1-30.

Gleadle, P. (2014) 'Restructuring and innovation in pharmaceuticals and biotechs: The impact of financialisation', Critical Perspectives on Accounting, 25. 1, 67-77.

Gorz, A. (2010) The Immaterial: Knowledge, Value and Capital. London and New York: Seagull Books.

Graduate Fog (2013) Law graduates skint and jobless as training contracts dry up, June 28, http://graduatefog.co.uk/2013/2600/law-graduate-jobs-training-contracts-deshudson/, date accessed 18 July 2016.

Graeber, David 2008, The sadness of post-workerism or "Art and Immaterial Labour" conference: A sort of review. Tate Britain. The Commoner, April 2008, https://libcom.org/files/graeber sadness.pdf, date accessed 18 July 2016. 
Hardt, M. and Negri, A. (1994) Labor of Dionysus: A Critique of the State-Form, Minneapolis: University of Minnesota Press.

Henwood, D. (2015) Workers Aren't Disappearing, The Jacobin (20), https://www.jacobinmag.com/2015/07/mason-guardian-capitalism-new-economypost-work/, date accessed 22 July 2016.

Huws, U (ed) 2007: Defragmenting: Towards a Critical Understanding of the New Global Division of Labour. London: Merlin.

Inman, P. (2016) Unemployment at lowest level for 11 years, The Guardian 16 June, p. 27.

Jeon, H. (2010) 'Cognitive Capitalism or Cognition in Capitalism? A Critique of Cognitive Capitalism Theory', Spectrum: Journal of Global Studies, 3, 89-116.

Johns, J. (2006) 'Video games production networks: value capture, power relations and embeddedness', Journal of Economic Geography 6, 151-180.

Keen, A. (2015) The Internet is Not the Answer, Atlantic Books: London.

Lazzarato, M. (1996) 'Immaterial labour' in: P. Virno and M. Hardt (eds.) Radical thought in Italy. Minneapolis: University of Minnesota Press, 132-146.

Lucarelli, S. and Vercellone, C. (2013) 'The Thesis of Cognitive Capitalism. New Research Perspectives. An Introduction', Knowledge Cultures 1, 4, 15-27.

Martin, C. B. and Deuze, M. (2009) 'The independent production of culture: a digital games case study', Games and Culture 4,3, 276-95.

Metz, C (2015) Why WhatsApp Only Needs 50 Engineers for Its 900M Users. 15 September 2015, http://www.wired.com/2015/09/whatsapp-serves-900-million-users-50engineers/, date accessed 16 July 2016

Mims, C. (2015) People Analytics: You're not a human, you're a data point', Wall Street Journal, 16th February.

Moulier-Boutang, Y. (2012) Cognitive Capitalism, Polity Press, Cambridge und Malden M.A.

Myers, J (2016): What do the world's 4 biggest companies have in common?, blog published 2 February 2016, https://www.weforum.org/agenda/2016/02/what-do-the-world-s4-biggest-companies-have-in-common/, date accessed 16 July 2016

Parker, R., Cox, S. and Thompson, P. (2014) 'How technological change affects power relations in global markets: remote developers in the console and mobile games industry', Environment and Planning A, 46, 168 - 185.

Shirky, C. (2009) Cognitive Surplus: Creativity and Generosity in a Contested Age, London: Penguin.

Smith, T. (2013) 'The 'General Intellect' in the Grundrisse and Beyond', Historical Materialism 21, 4, 235-255. 
Srnicek, N. and Williams, A. (2015) Inventing the future: Postcapitalism and a world without work. London: Verso Books.

Stewart, I., De, D. and Cole, A. (2015) Technology and People: the Great Job Creating Machine, Report, London: Deloitte.

Taylor, P. (2013) Performance Management and the New Workplace Tyranny. A Report for the Scottish Trade Union Congress, Glasgow: University of Strathclyde.

Terranova, T. (2008) 'Free Labor: Producing Culture for the Digital Economy', Social Text, 63, $18,2,33-58$.

Thompson, P. (2013) 'Financialization and the Workplace: Extending and Applying the Disconnected Capitalism Thesis', Work, Employment and Society, 25th Anniversary edition, $27,3,472-88$.

Thompson, P. and Smith, C. (2009) 'Labour Power and Labour Process: Contesting the Marginality of the Sociology of Work', Sociology, 43, 5, 913-930.

Thompson, Paul und Jean Cushen 2015: Financialization and Value Extraction: Why Labour and the Labour Process Still Matters, in: Work, Employment and Society, In Review.

Thompson, P., Parker, R. and Cox, S. (2015) 'Interrogating Creative Theory and Creative Work: Inside the Games Studio', Sociology. OnlineFirst, 17 February.

Thompson, P., Parker, R. and Cox, S. (2015) 'Labour and Asymmetric Power Relations in Global Value Chains: The Digital Entertainment Industries and Beyond' in: K. Newsome, P. Taylor, J. Bair and A. Rainnie (eds) Putting Labour in its Place? Labour Process Analysis and Global Value Chains, Houndmills: Palgrave, 45-63.

Turchetto, M. (2008): 'From 'Mass Worker' to 'Empire': The Disconcerting Trajectory of Italian Operaismo' in: J. Bidet and S. Kouvelakis (eds) Critical Companion to Contemporary Marxism, Boston: Brill, 285-308.

Vercellone, C. (2007) 'From Formal Subsumption to General Intellect: Elements for a Marxist Reading of the Thesis of Cognitive Capitalism', Historical Materialism 15, 13-36.

Warhurst, C. and Thompson, P. (2006) 'Mapping knowledge in work: Proxies or Practices?', Work, Employment and Society, 20, 4, 787-800.

Westkämper, E. (2007): 'Digital Manufacturing in the Global Era' in P.F. Cunha and P.G. Maropoulos (eds) Digital enterprise technology: perspectives and future challenges, Springer, New York, 3-14.

Willmott, H. (2010). 'Creating 'value' beyond the point of production: branding, financialization and market capitalization', Organization, 17,5, 517-542.

Wolkowitz, C. and Warhurst, C (2010) 'Embodying Labour' in: P. Thompson and C. Smith (eds) Working Life: Renewing Labour Process Analysis, Basingstoke: Palgrave, 223243. 
Worldbank (2016) Labor force participation rate, total (\% of total population ages 15+)

(modelled ILO estimate), http://data.worldbank.org/indicator/SL.TLF.CACT.ZS, date accessed 18 July 2016.

Wright, J. and Sissons, P. (2012) The Skills Dilemma: Skills Under-utilisation and Low-Waged Work, London: The Work Foundation. 
Table 1: Job growth US labour market 2014-2024

\begin{tabular}{|c|c|c|}
\hline **bold: high(er) skilled knowledge/creative work; italic: manual work; & $\begin{array}{r}\text { Total, all } \\
\text { occupations } \\
9,788.90 \\
\end{array}$ & $\begin{array}{r}\text { in } \% \\
6.5 \\
\end{array}$ \\
\hline Personal care aides & 458.1 & 25.9 \\
\hline Registered nurses & 439.3 & 16.0 \\
\hline Home health aides & 348.4 & 38.1 \\
\hline $\begin{array}{l}\text { Combined food preparation and serving workers, including fast } \\
\text { food }\end{array}$ & 343.5 & 10.9 \\
\hline Retail salespersons & 314.2 & 6.8 \\
\hline Nursing assistants & 262.0 & 17.6 \\
\hline Customer service representatives & 252.9 & 9.8 \\
\hline Cooks, restaurant & 158.9 & 14.3 \\
\hline General and operations managers & 151.1 & 7.1 \\
\hline Construction laborers & 147.4 & 12.7 \\
\hline Accountants and auditors & 142.4 & 10.7 \\
\hline Medical assistants & 138.9 & 23.5 \\
\hline Janitors and cleaners, except maids and housekeeping cleaners & 136.3 & 5.8 \\
\hline Software developers, applications & 135.3 & 18.8 \\
\hline Laborers and freight, stock, and material movers, hand & 125.1 & 5.1 \\
\hline First-line supervisors of office and administrative support workers & 121.2 & 8.3 \\
\hline Computer systems analysts & 118.6 & 20.9 \\
\hline Licensed practical and licensed vocational nurses & 117.3 & 16.3 \\
\hline Maids and housekeeping cleaners & 111.7 & 7.7 \\
\hline Medical secretaries & 108.2 & 20.5 \\
\hline Management analysts & 103.4 & 13.6 \\
\hline Heavy and tractor-trailer truck drivers & 98.8 & 5.5 \\
\hline Receptionists and information clerks & 97.8 & 9.5 \\
\hline Office clerks, general & 95.8 & 3.1 \\
\hline $\begin{array}{l}\text { Sales representatives, wholesale and manufacturing, except } \\
\text { technical and scientific products }\end{array}$ & 93.4 & 6.4 \\
\hline Stock clerks and order fillers & 92.9 & 4.9 \\
\hline Market research analysts and marketing specialists & 92.3 & 18.6 \\
\hline First-line supervisors of food preparation and serving workers & 88.5 & 9.9 \\
\hline Electricians & 85.9 & 13.7 \\
\hline Maintenance and repair workers, general & 83.5 & 6.1 \\
\hline
\end{tabular}

Source: Bureau of Labor Statistics (2016), own table 